Proc. Estonian Acad. Sci. Geol., 1999, 48, 4, 195-212

\title{
PLATYSTROPHIA (ORTHIDA, BRACHIOPODA) FROM THE ARENIG AND LOWERMOST LLANVIRN OF NORTHWESTERN RUSSIA
}

\author{
Michael A. ZUYKOV
}

Department of Paleontology, St. Petersburg State University, 16 Liniya 29, 199178 St. Petersburg, Russia; zuykov@riand.spb.su

Received 12 January 1999, in revised form 19 April 1999

\begin{abstract}
Six species of the genus Platystrophia (Plectorthidae, Orthida) are described from the Arenig and lowermost Llanvirn of the Baltic-Ladoga Klint, northwestern Russia. One taxon represents an earlier known species, one a new species, and four forms are described in open nomenclature. The oldest species of the genus in the Ordovician of Baltoscandia are Platystrophia sp. a Rubel, 1961 and Platystrophia? sp. 1 (in this paper) from the Volkhov Stage (upper part of the Baltoniodus triangularis-B. navis conodont Zone) of the St. Petersburg region. The lack of granulation on the shell makes the generic attribution of both species tentative.

The distribution of the genus Platystrophia in the upper Arenig-lower Llanvirn of Russia, Wales, North America, South America, and China is discussed. The earliest known species of the genus is Platystrophia sp. from the Niquivilia brachiopod Zone (lower part of the B. triangularis$B$. navis Zone) of the Argentine Precordillera. This species has no granulation on the well-preserved shell; therefore its generic position should be confirmed by further study.
\end{abstract}

Key words: Brachiopoda, Platystrophia, Ordovician, Arenig, Llanvirn, Russia.

\section{INTRODUCTION}

The genus Platystrophia King, 1850 includes one of the most distinctive and widespread brachiopods in the Ordovician of Baltoscandia, which makes its first appearance in the late Arenig (Volkhov Stage) and ranges up into the Wenlock (Jaagarahu Stage). The main task of the present paper is to revise the earliest Arenig-Llanvirn species of Platystrophia from the Lower Palaeozoic outcrop area along the eastern part of the Baltic-Ladoga Klint (Fig. 1). 


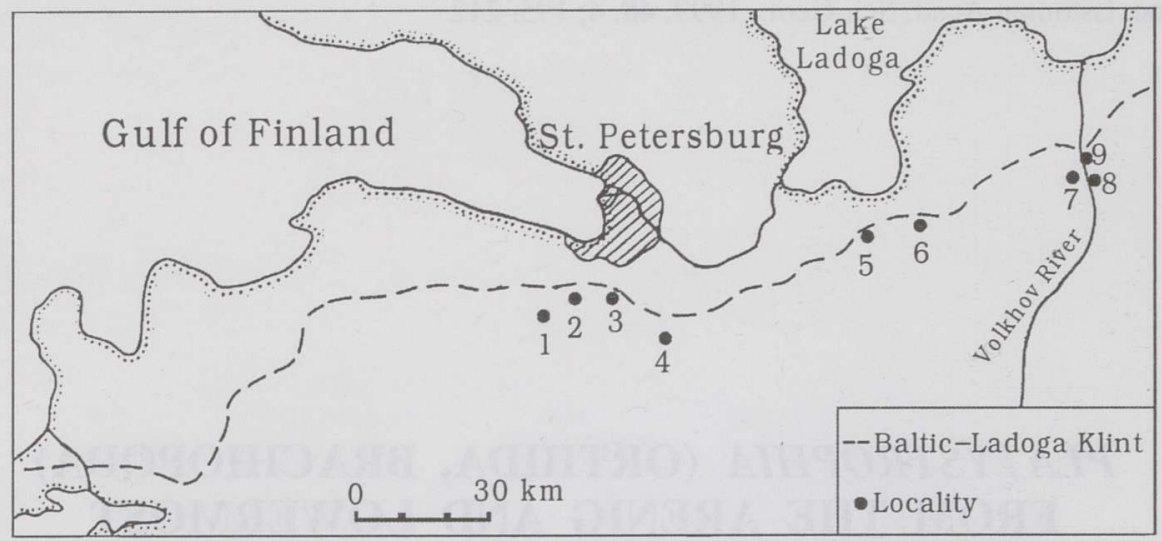

Fig. 1. Map of the study area. 1, Kipen village; 2, Kirchoff Mountain; 3, Pulkovka River; 4, Popovka River; 5, Putilovo quarry; 6, Lava River; 7, Izvoz village; 8, Simankovo village; 9, Babino quarry.

In the St. Petersburg region, in terms of regional stratigraphical units from the Volkhov to Kunda stages of the Oeland Series, the studied interval is mostly represented by glauconitic (Volkhov Formation) and oolitic (Obukhovo Formation) limestones. It has been discussed in a number of recent publications (Dronov \& Fedorov, 1995; Dronov et al., 1996, 1998). The lithostratigraphic subdivisions of the Volkhov and Kunda stages described in these publications are used here to characterize the stratigraphic distribution of the earliest Baltic Platystrophia (Fig. 2).

The figured specimens under the collection number 12974 are deposited in the Central Scientific-Research Geological Exploration Museum named after F. N. Chernyshev (CNIGR), St. Petersburg, where also A. von Volborth's collection No. 13017 is housed. Two specimens (one of them figured) of Platystrophia costata from the collection of C. H. Pander (MMI 373) are housed in the Museum of the Mining Institute, St. Petersburg.

\section{DISTRIBUTION OF THE EARLIEST PLATYSTROPHIA}

The earliest finds of Platystrophia come from the upper Arenig-lower Llanvirn of northwest Russia, Wales, North America, South America, and China (Fig. 3). Platystrophia sp. a Rubel, 1961 and Platystrophia? sp. 1 (in this paper) from the Volkhov Stage of the St. Petersburg region are tied to the upper part of the Baltoniodus triangularis-B. navis conodont Zone (for zones see Fortey et al., 1995; Dronov et al., 1998). This is the earliest known occurrence of Platystrophia in Baltoscandia. These species, as well as two unnamed species described here 


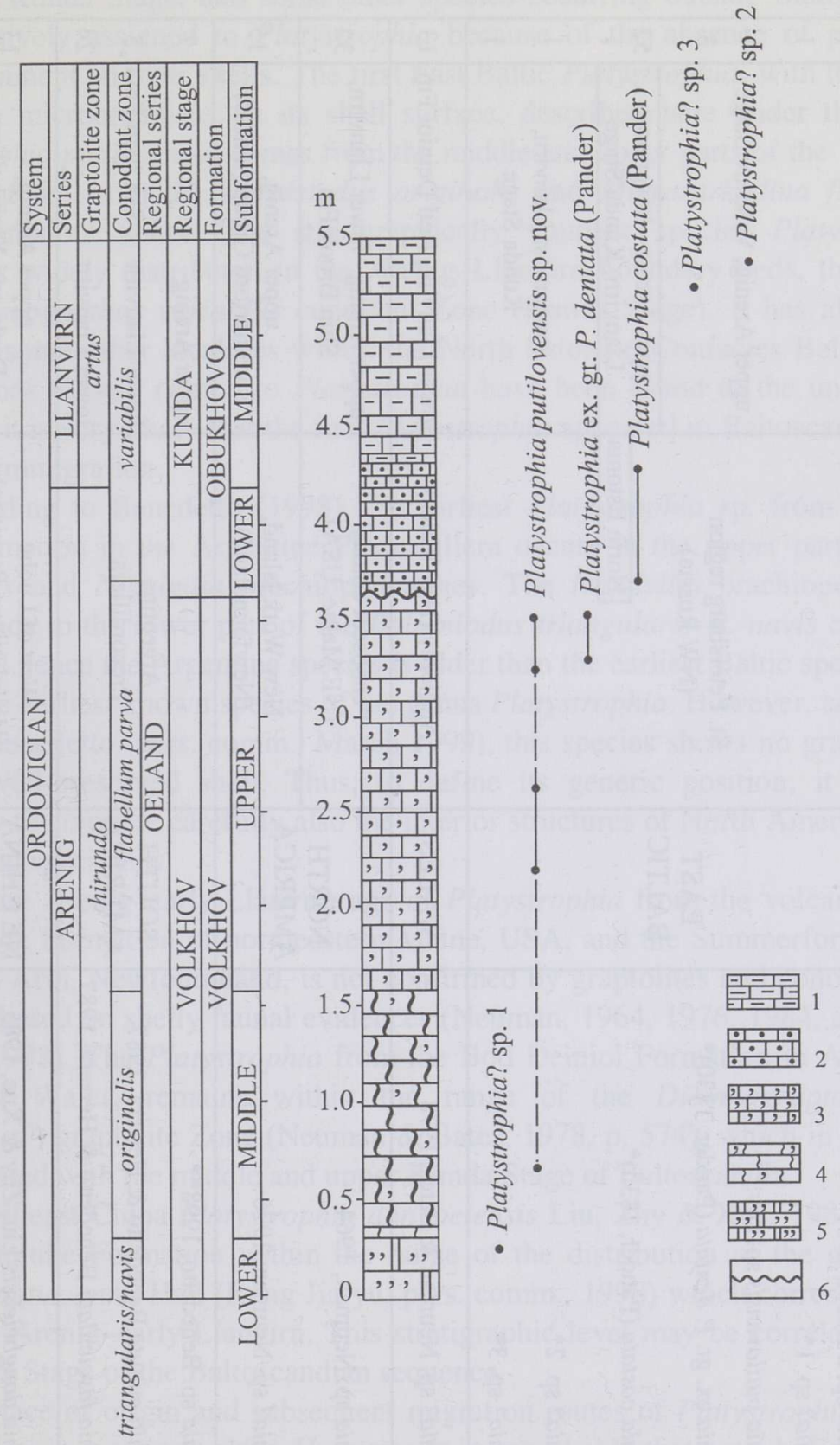

Fig. 2. Distribution of Platystrophia in the Volkhov and Kunda stages in the eastern Baltic-Ladoga Klint (generalized section of the Volkhov and Obukhovo formations based on the data of Dronov \& Fedorov, 1995; Dronov at al., 1996). Key: 1, "orthoceratite" limestone; 2, "lower oolite layer"; $3-5$, glauconite limestone; 6 , unconformity. 


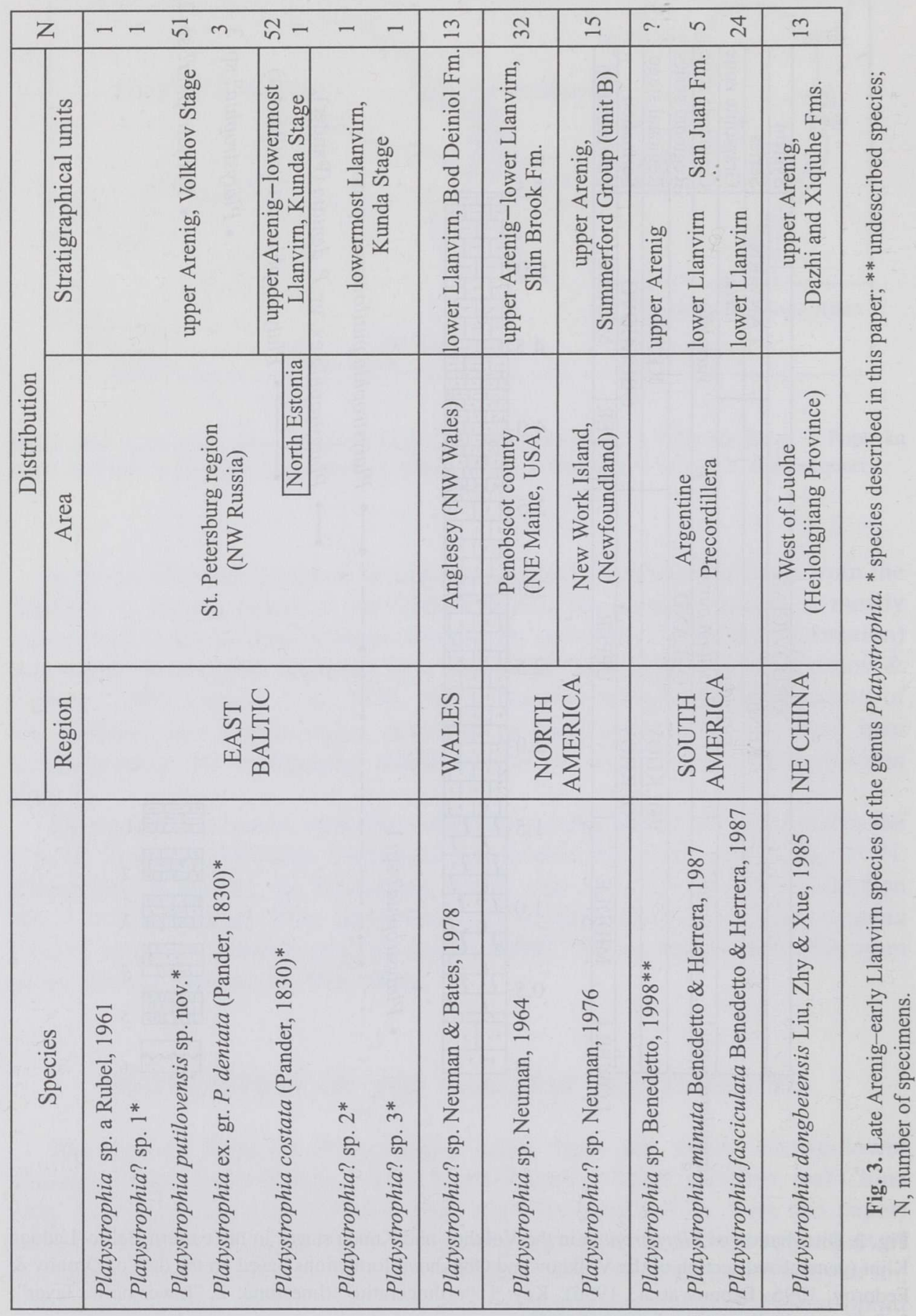


from the Kunda Stage, and some other species occurring outside Baltoscandia, are tentatively assigned to Platystrophia because of the absence of pustulose microornament on their shells. The first East Baltic Platystrophia, with the finely pustulose microornament on its shell surface, described here under the name Platystrophia putilovensis, comes from the middle and upper parts of the Volkhov Stage, that is, from the Paroistodus originalis and Microzarkodina flabellum parva conodont zones. The stratigraphically younger species Platystrophia costata is widely distributed in the Arenig-Llanvirn boundary beds, that is, in the Eoplacognathus variabilis conodont Zone (Kunda Stage). It has also been found in some other localities within the North Estonian Confacies Belt. As no brachiopods closely related to Platystrophia have been found in the underlying deposits, it is very likely that the first Platystrophia appeared in Baltoscandia as a result of immigration.

According to Benedetto (1998), the earliest Platystrophia sp. from the San Juan Formation in the Argentine Precordillera occurs in the upper parts of the Monorthis and Niquivilia brachiopod zones. The Niquivilia brachiopod Zone corresponds to the lower part of the Baltoniodus triangularis-B. navis conodont Zone, and hence the Argentine species is older than the earliest Baltic species and can be the earliest known species of the genus Platystrophia. However, according to J. L. Benedetto (pers. comm., March 1999), this species shows no granulation on the well-preserved shell. Thus, to define its generic position, it will be necessary to compare carefully also the interior structures of North American and East Baltic specimens.

The late Arenig-early Llanvirn age of Platystrophia from the volcanoclastic Shin Brook Formation of northeastern Maine, USA, and the Summerford Group in Virgin Arm, Newfoundland, is not confirmed by graptolites and conodonts; it is solely based on shelly faunal evidences (Neuman, 1964, 1976, 1984, and pers. comm., 1998). The Platystrophia from the Bod Deiniol Formation in Anglesey, northwest Wales, remains within the range of the Didymograptus artus (= "bifidus") graptolite Zone (Neuman \& Bates, 1978, p. 574), which in turn can be correlated with the middle and upper Kunda Stage of Baltoscandia.

In northeast China Platystrophia dongbeiensis Liu, Zhy \& Xue, 1985 occurs in the Xiqiuhe Formation within the range of the distribution of the graptolite Phyllograptus anna Hall (Rong Jia-yu, pers. comm., 1998) which corresponds to the latest Arenig-early Llanvirn. This stratigraphic level may be correlated with the Kunda Stage of the Baltoscandian sequence.

The place of origin and subsequent migration routes of Platystrophia during the pre-Arenig remain unclear. However, it is remarkable that outside East Baltic all known early Ordovician occurrences of the genus are reported from microplates, separated from major land massifs in the early Ordovician (e.g. Avalonian Plate), or suspect terranes with complicated early Palaeozoic geological history. 


\title{
SYSTEMATIC DESCRIPTIONS
}

\author{
Family PLECTORTHIDAE SCHUCHERT, 1929 \\ Subfamily PLATYSTROPHIINAE SCHUCHERT, 1929 \\ Genus Platystrophia King, 1850
}

Type species. Terebratulites biforatus von Schlotheim, 1820, from the Ordovician of the Baltic area (exact locality and horizon uncertain).

Platystrophia costata (Pander, 1830)

Plate I, figures 1-14; Figure 4; Table 1

1830 Porambonites costatus n. sp.; Pander, p. 96, pl. XI, fig. 3.

1837 Spirifer chama Eichwald; Buch, p. 34.

1840 Spirifer chama Eichwald; Buch, p. 180.

1841 Spirifer chama Eichwald, p. 31.

1845 Spirifer biforatus var. chama Eichwald (pars); Verneuil, p. 139, f. minor non f. major pl. V, fig. 1.

non 1861 Platystrophia costata Pander; Eichwald, p. 233.

1961 Platystrophia sp. c Rubel, p. 155, pl. I, fig. 7; pl. II, figs. 1-5.

1961 Platystrophia costata (Pander); Rubel, p. 156, pl. I, fig. 8.

Neotype. Selected here: complete shell MMI 1/373, collection of C. H. Pander of 1845, Pulkovka River, St. Petersburg region (horizon is not specified, probably from the Kunda Stage, Obukhovo Formation).

Pander (1830) did not select the holotype. The collection used in that paper was lost by the beginning of the 20th century. However, two complete shells of Platystrophia from Pander's collection of 1845, MMI 373, were identified by him as Spirifer biforatus var. chama from the Pulkovka River, St. Petersburg region. This identification is considered to be synonymous to Porambonites costata

\section{Explanation of Plate I}

Figs. 1-10. Platystrophia costata (Pander). 1-5, MMI 1/373; ventral, dorsal, lateral, anterior, and posterior views of conjoined valves; Pulkovo village; coll. by C. H. Pander, 1845. 6, CNIGR Museum 5/12974; anterior view of conjoined valves. 7-9, CNIGR Museum 4/12974; ventral, lateral, and posterior views of conjoined valves; Lava River; Kunda Stage. 10, CNIGR Museum 7/12974; interior of dorsal valve; Putilovo quarry; Kunda Stage; coll. by the author.

Figs. 11-14. Platystrophia cf. P. costata (Pander). CNIGR Museum 6/12974; ventral, dorsal, anterior, and posterior views of conjoined valves; Putilovo quarry; Kunda Stage; coll. by the author. Figs. $1-9,11-14 \times 3$; fig. $10 \times 5$. 


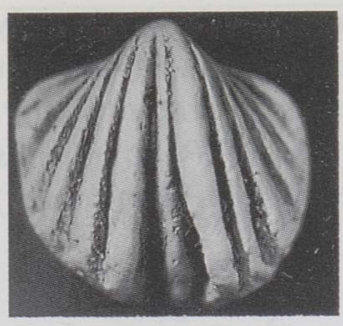

1

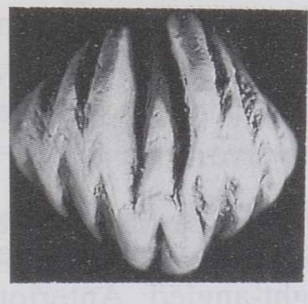

4
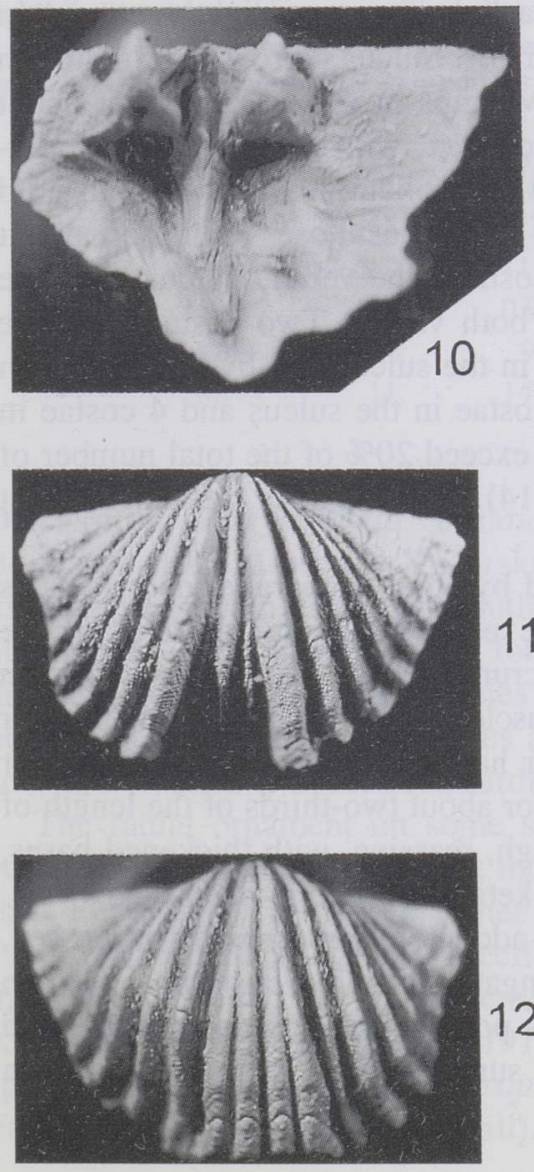

11

12

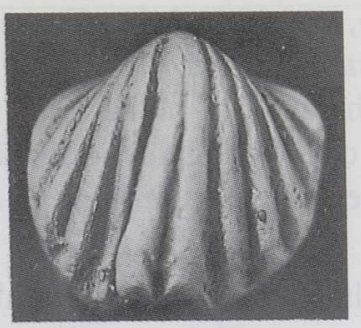

2

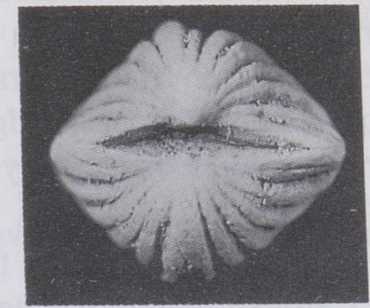

3
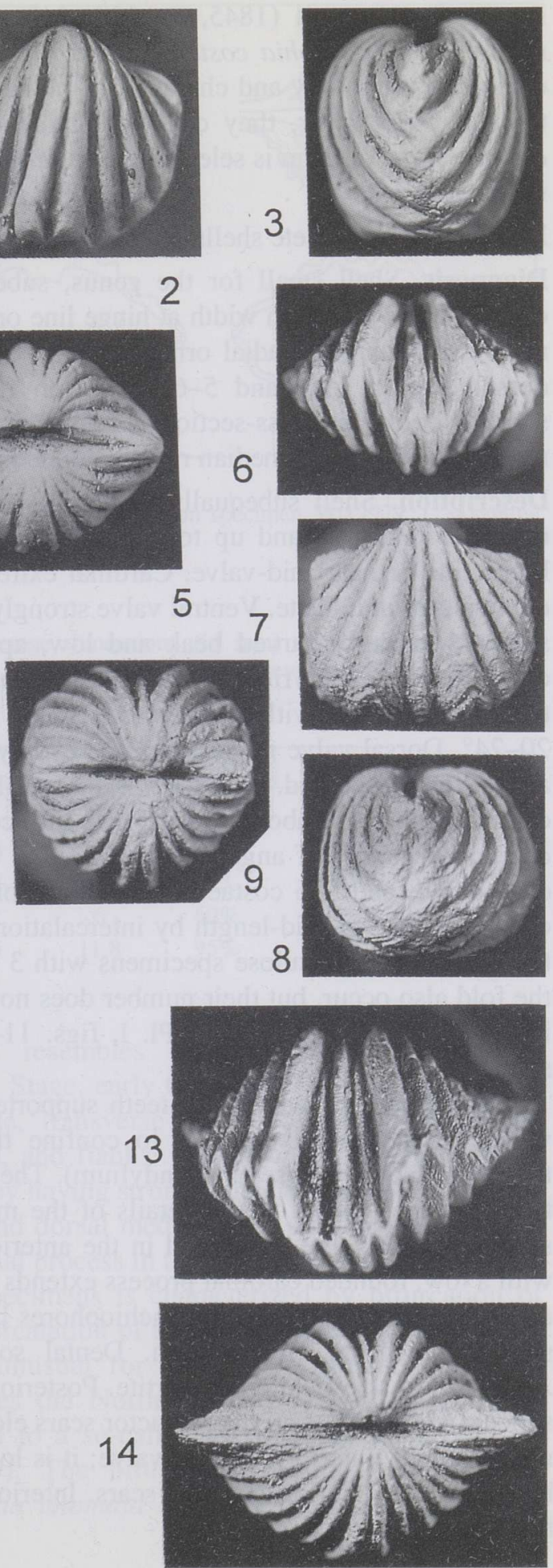
Pander by Verneuil (1845, pp. 139, 140). These specimens, indeed, strongly resemble Platystrophia costata, as described and illustrated by Pander, in their external morphology and character of radial ornament. Because of their locality, the Pulkovka River, they can be regarded as the topotypes of Porambonites costatus. One of them is selected as the neotype of Platystrophia costata (Pander) in this paper.

Material. 35 complete shells, 9 ventral and 8 dorsal valves.

Diagnosis. Shell small for the genus, subequally biconvex, subrectangular in outline, with maximum width at hinge line or near mid-valve; cardinal extremities nearly right-angled; radial ornament with 1 costa in ventral sulcus, 2 costae in dorsal median fold, and 5-6 costae on flanks; brachiophore bases massive, subrhomboidal in cross-section; cardinal process ridge-like, situated on a wide notothyrial platform; median ridge extended anteriorly to mid-valve.

Description. Shell subequally biconvex, transverse, subrectangular in outline, up to $11 \mathrm{~mm}$ long and up to $14.5 \mathrm{~mm}$ wide, with the maximum width at the hinge line or near mid-valve. Cardinal extremities nearly right-angled. Anterior commissure uniplicate. Ventral valve strongly and evenly convex, with somewhat swollen, strongly curved beak and low, apsacline interarea slightly curved in cross-section. Delthyrium open, triangular, narrow. Sulcus narrow, originating in the umbonal area, with steep lateral slopes. Margins of sulcus diverge at about $20-24^{\circ}$. Dorsal valve moderately and evenly convex, with low, orthocline interarea, slightly curved. Beak incurved, slightly swollen. Narrow median fold originates in the umbonal area. Shell surface finely pustulose. Radial ornament composed mainly of angular costae, with 1 costa in the ventral sulcus, 2 in the dorsal fold, and 5-6 costae on the flanks of both valves. Two costae originate occasionally near mid-length by intercalation in the sulcus and by bifurcation in the fold. Finely pustulose specimens with 3 costae in the sulcus and 4 costae in the fold also occur, but their number does not exceed $20 \%$ of the total number of individuals in the collection (Pl. I, figs. 11-14). Growth lines present in most specimens.

Ventral interior with small teeth supported by stout subparallel dental plates which extend to the anterior to confine the ellipsoidal muscle field on the thickened platform (pseudospondylium). The crural fossettes are very shallow on the inner face of the teeth. Details of the muscle scars are not known. Interior surface of the valve crenulated in the anterior half of the valve. Dorsal interior with a low, rounded cardinal process extends for about two-thirds of the length of a wide notothyrial platform. Brachiophores high, massive, with thickened bases, subrhomboidal in cross-section. Dental sockets moderately deep and wide. Adductor muscle field quadripartite. Posterior adductor scars strongly impressed, suboval in outline. Anterior adductor scars elongate ellipsoidal in outline. Median ridge extends anteriorly to mid-valve; it is low posteriorly and becomes thin and high between anterior adductor scars. Interior surface of the valve crenulated in the anterior half of the valve. 


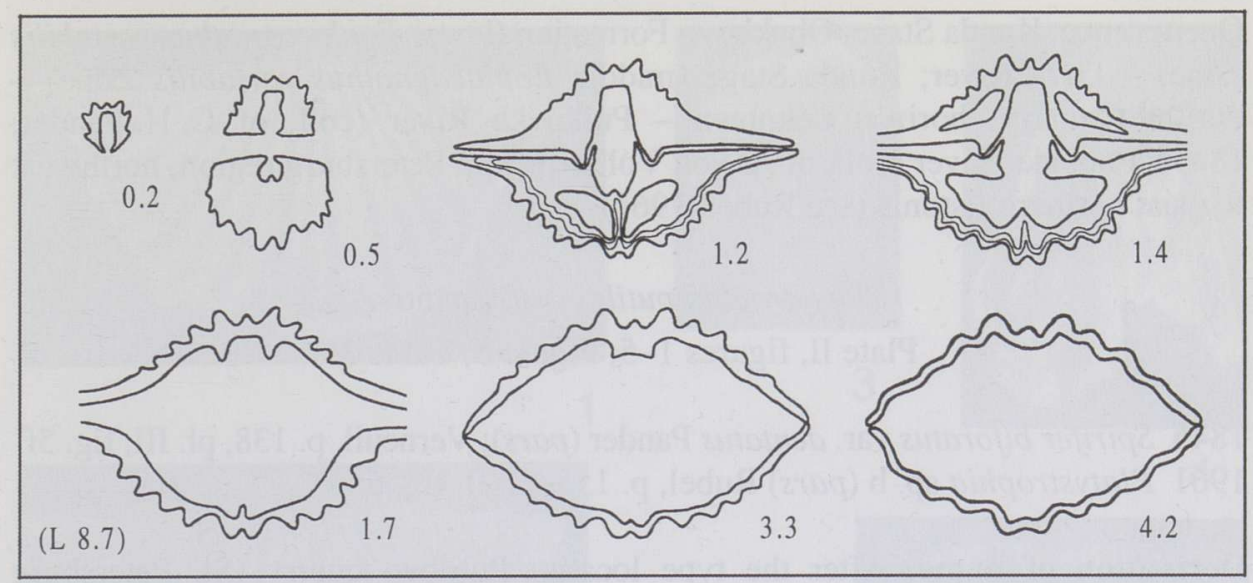

Fig. 4. Serial sections of Platystrophia costata (Pander) based on specimen 31/12974. L = sagittal length. Measurements in $\mathrm{mm} . \times 2.5$.

Table 1. Platystrophia costata (Pander), average dimensions (in $\mathrm{mm}$ ) of 13 complete shells. $\mathrm{L}=$ sagittal length, $\mathrm{W}=$ width, $\mathrm{T}=$ thickness, $\mathrm{X}=$ mean, $\mathrm{S}=$ standard deviation, $\mathrm{MIN}=$ minimum value, $\mathrm{MAX}=$ maximum value, $\mathrm{N}=$ number of specimens

\begin{tabular}{l|c|c|c|c|c}
\hline & $\mathrm{L}$ & $\mathrm{W}$ & $\mathrm{T}$ & $\mathrm{L} / \mathrm{W}$ & $\mathrm{T} / \mathrm{L}$ \\
\hline $\mathrm{N}$ & 13 & 13 & 12 & 13 & 12 \\
$\mathrm{X}$ & 9.7 & 11.8 & 9.3 & $83 \%$ & $96 \%$ \\
$\mathrm{~S}$ & 0.97 & 0.97 & 1.63 & 7.3 & 12.9 \\
MIN & 7.6 & 9 & 6 & $69 \%$ & $77 \%$ \\
MAX & 11 & 14.5 & 11.8 & $95 \%$ & $114 \%$
\end{tabular}

Discussion. Platystrophia costata resembles Platystrophia pseudocostata Bondarev (1968) from the Yugorskii Stage, early Caradoc of Vaigach Island, in its rounded rectangular shell outline, transverse profile of both valves, and number of costae in the sulcus, fold, and flanks. Platystrophia costata may be distinguished from the latter species by having strongly incurved swollen beaks in both valves, narrow ventral sulcus and dorsal median fold, smaller and rounded costae, as well as low, rounded cardinal process in the dorsal valve.

The radial ornament on some specimens is characterized by bifurcation of costae in the dorsal median fold; intercalation of two costae in the ventral sulcus (see Pl. I, figs. 11-14) is rather unusual for the Baltoscandian species of Platystrophia. Such pattern specifies the North American representatives of the genus which have been referred to a so-called tricostate group of species (Cummings, 1903; McEwan, 1919). The bifurcation occurs also in some specimens of unicostate Platystrophia anomala Hiller (1980) from the Dolhir Formation of North Wales (Ashgill). 
Occurrence. Kunda Stage, Obukhovo Formation (lower Eoplacognathus variabilis Zone) - Lava River; Kunda Stage (middle Eoplacognathus variabilis Zone) Putilovo quarry; horizon unknown - Pulkovka River (coll. of C. H. Pander, 1845); Popovka River (coll. of A. von Volborth); St. Petersburg region, northwest Russia; northern Estonia (see Rubel, 1961).

\section{Platystrophia putilovensis sp. nov.}

Plate II, figures 1-5; Figure 5; Table 2

1845 Spirifer biforatus var. dentatus Pander (pars); Verneuil, p. 138, pl. III, fig. $5 f$. 1961 Platystrophia sp. b (pars) Rubel, p. 155, pl. II, fig. 6.

Derivation of name. After the type locality Putilovo quarry (St. Petersburg region).

Holotype. Complete shell, CNIGR 9/12974, from the Volkhov Stage, Volkhov Formation (Paroistodus originalis Zone), Putilovo quarry, St. Petersburg region, coll. by the author; Pl. II, figs. 1-3.

Material. 3 complete shells, 22 ventral and 26 dorsal valves.

Diagnosis. Shell small for genus, subequally biconvex, trapezoidal in outline, with maximum width at hinge line; cardinal extremities acute; radial ornament with 2 costae in ventral sulcus, 3 costae in dorsal median fold, and 6-7 costae on flanks; brachiophore bases triangular in cross-section; cardinal process simple, ridge-like; dorsal median ridge high, about two-thirds of valve length.

Description. Shell subequally biconvex, trapezoidal in outline, with maximum width along the hinge line, up to $10.8 \mathrm{~mm}$ long and up to $19 \mathrm{~mm}$ wide. Cardinal

\section{Explanation of Plate II}

Figs. 1-5. Platystrophia putilovensis sp. nov. 1-3, CNIGR Museum 9/12974, holotype; ventral, dorsal, and lateral views of conjoined valves; Putilovo quarry; Volkhov Stage. 4, CNIGR Museum 27/12974; interior of ventral valve; Putilovo quarry; Volkhov Stage. 5, CNIGR Museum 10/12974; interior of dorsal valve; Putilovo quarry; Volkhov Stage; coll. by the author.

Figs. 6-9. Platystrophia ex. gr. P. dentata (Pander). 6-8, CNIGR Museum 20/12974; ventral, dorsal, and posterior views of conjoined valves; Putilovo quarry; Volkhov Stage; coll. by the author. 9, CNIGR Museum 19/12974; interior of dorsal valve; Volkhov River; Kunda Stage; coll. by S. S. Terentiev.

Figs. 10, 11. Platystrophia? sp. 1. CNIGR Museum 29/12974; exterior and interior of ventral valve; Putilovo quarry; Volkhov Stage; coll. by A. V. Dronov.

Fig. 12. Platystrophia? sp. 2. CNIGR Museum 21/12974; exterior of ventral valve; Kipen village; Kunda Stage; coll. by S. S. Terentiev.

Figs. 13, 14. Platystrophia? sp. 3. CNIGR Museum 22/12974; ventral and dorsal views of conjoined valves; Kirchoff Mountain, Kunda Stage; coll. by S. S. Terentiev.

Figs. $1-3,5-8,10-14 \times 3$; fig. $4 \times 5$; fig. $9 \times 2$. 
PLATE II

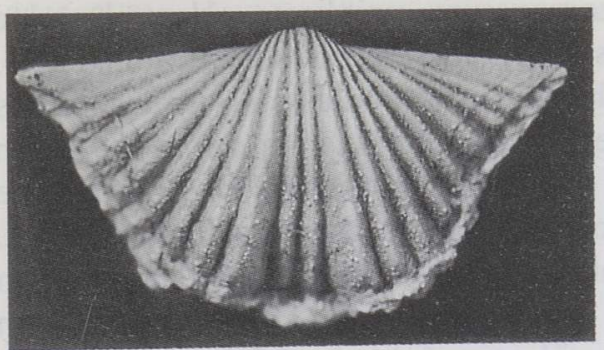

1

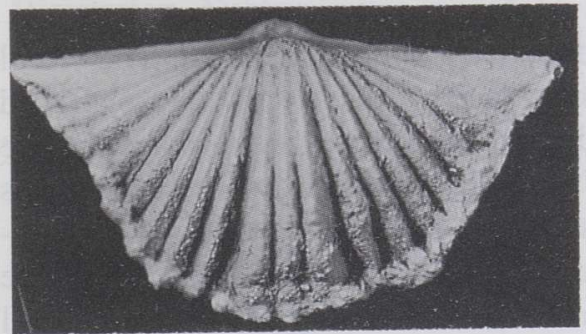

2
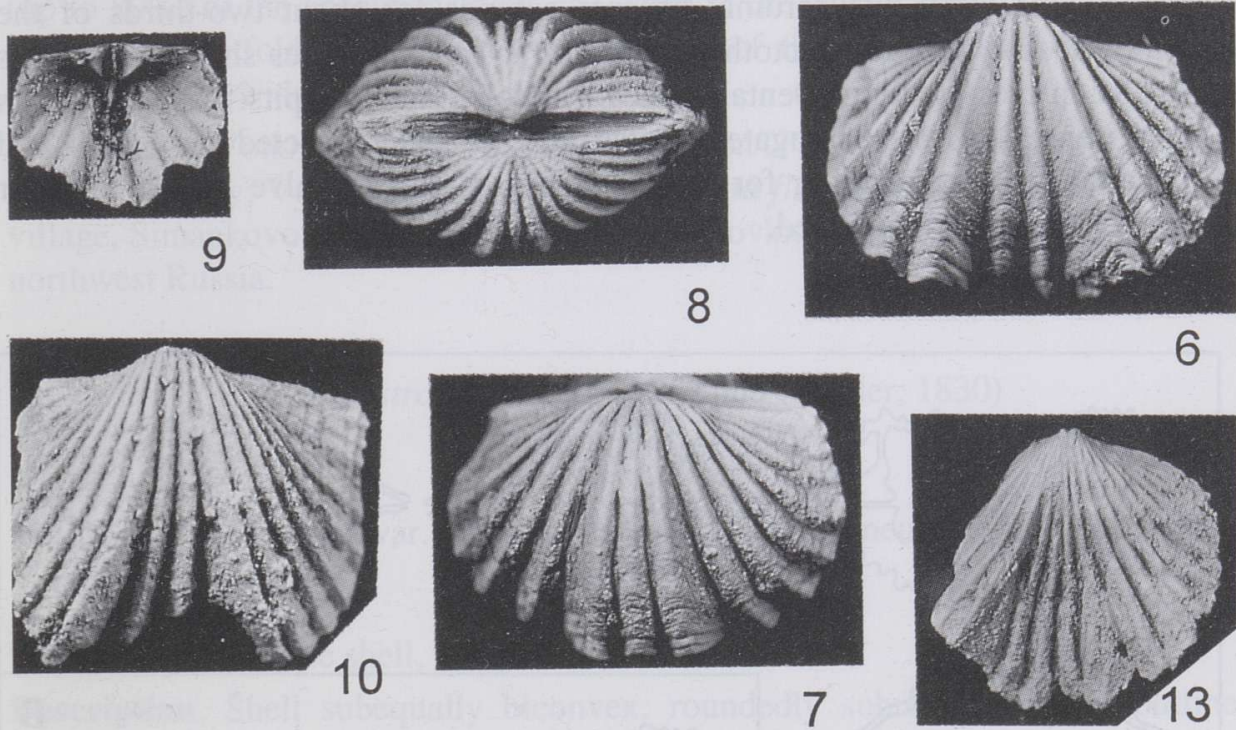

6
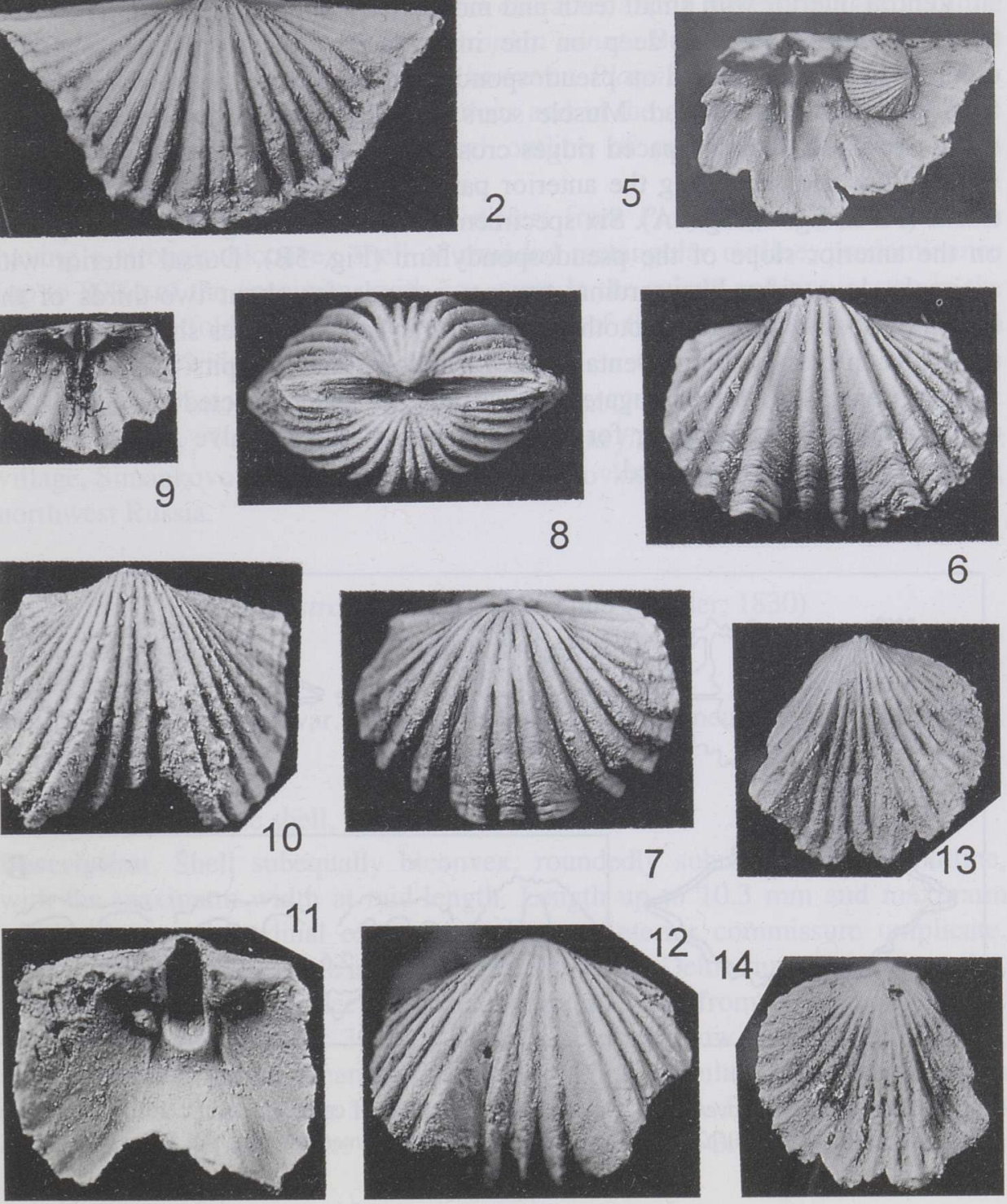

4
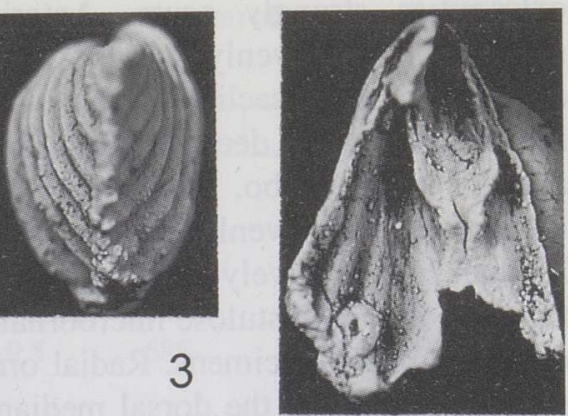

8

6 
extremities strongly acute. Anterior commissure uniplicate. Ventral valve moderately and evenly convex, with a slightly curved, pointed beak and low, almost planar, apsacline interarea. Delthyrium open, triangular, wide. Sulcus moderately wide, deep, with steep lateral sides, originating about $1-2 \mathrm{~mm}$ anterior to the umbo. Margins of sulcus diverge at about $20-23^{\circ}$. Dorsal valve moderately and evenly convex, with low, almost planar, anacline interarea. Median fold relatively low, with steep lateral slopes, originating about 1-2 mm from the umbo. Pustulose microornament can be observed in interspaces between costae in most specimens. Radial ornament costate, with 2 costae in the ventral sulcus, 3 costae in the dorsal median fold, and 6-7 costae on the flanks of both valves. Growth lines present.

Ventral interior with small teeth and moderately thin dental plates. The crural fossettes are moderately deep on the inner face of the teeth. Muscle field elongate, suboval, situated on pseudospondylium. Anterior margin of the muscle field concentrically striated. Muscle scars not clearly defined. Two specimens show two short, closely spaced ridges crossing the anterior slope of the pseudospondylium and separating the anterior part of weakly impressed linear muscle tracks (Pl. II, fig. 4; Fig. 5A). Six specimens have a thickening of secondary shell on the anterior slope of the pseudospondylium (Fig. 5B). Dorsal interior with a simple, low, ridge-like cardinal process extends for about two-thirds of the length of a wide and deep notothyrial platform. Brachiophores short, with bases triangular in cross-section. Dental sockets shallow, like oval pits. Adductor scars weakly impressed, with elongate suboval anterior pair, bisected by a high and thin median ridge extending for about two-thirds of the valve length. Interior surface of the valve crenulated.

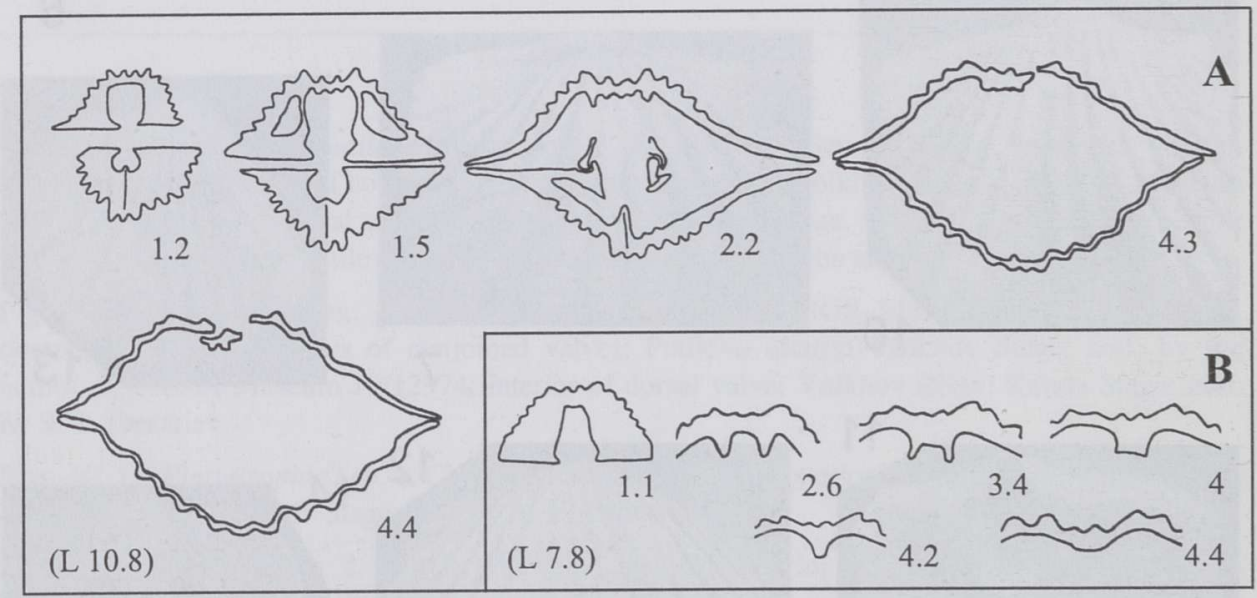

Fig. 5. Platystrophia putilovensis sp. nov. (A) Serial sections of complete shell 1/13017. (B) Serial sections of ventral valve $30 / 12974$. L = sagittal length. Measurements in mm. All figures $\times 2$. 
Table 2. Platystrophia putilovensis sp. nov., average dimensions (in $\mathrm{mm}$ ) of one complete shell and six dorsal valves. For abbreviations see Table 1

\begin{tabular}{l|c|c|c|c|c}
\hline & $\mathrm{L}$ & $\mathrm{W}$ & $\mathrm{T}$ & $\mathrm{L} / \mathrm{W}$ & $\mathrm{T} / \mathrm{L}$ \\
\hline $\mathrm{N}$ & 7 & 7 & 2 & 7 & 2 \\
$\mathrm{X}$ & 8.8 & 16.7 & 7.75 & $53 \%$ & $76 \%$ \\
$\mathrm{~S}$ & 1.23 & 1.14 & 2.47 & 7.6 & 17.5 \\
MIN & 7 & 15.8 & 6 & $44 \%$ & $63 \%$ \\
MAX & 10.8 & 19 & 9.5 & $68 \%$ & $88 \%$
\end{tabular}

Discussion. Subtriangular, widening anteriorly brachiophore bases are the most distinctive feature of this species. In this character and in trapezoidal shell outline the species is comparable with Platystrophia minuta Benedetto \& Herrera (1987) from the early Llanvirn of Argentina, however, Platystrophia putilovensis differs in having less costae in the ventral sulcus and in the dorsal median fold, visible impressed anterior adductors, suboval outline of posterior adductors, and a shorter, wider cardinal process.

Platystrophia costata (see above) differs from Platystrophia putilovensis in having a strongly biconvex shell of rounded rectangular outline, predominance (up to $80 \%$ ) of the specimens with one costa in the sulcus and two costae in the dorsal median fold, rhomboidal cross-section of the brachiophore base, and a relatively narrow delthyrium.

Occurrence. Volkhov Stage, Volkhov Formation (Paroistodus originalis Zone) Putilovo quarry; Volkhov Stage (Microzarkodina flabellum parva Zone) - Izvoz village, Simankovo village, Babino quarry, Popovka River; St. Petersburg region, northwest Russia.

Platystrophia ex. gr. P. dentata (Pander, 1830)

Plate II, figures 6-9

1845 Spirifer biforatus var. dentatus Pander (pars); Verneuil, p. 138, pl. III, figs. 5a-e.

Material. 1 complete shell, 2 dorsal valves.

Description. Shell subequally biconvex, roundedly subrectangular in outline, with the maximum width at mid-length. Length up to $10.3 \mathrm{~mm}$ and maximum width $13.1 \mathrm{~mm}$. Cardinal extremities obtuse. Anterior commissure uniplicate. Ventral valve with apsacline interarea, slightly curved. Delthyrium open, triangular, moderately wide. Sulcus deep, originating about $1 \mathrm{~mm}$ from the umbo. Margins of sulcus diverge at about $30-34^{\circ}$. Dorsal valve with low, orthocline interarea, slightly curved. Radial ornament composed of high angular costae, two of them in the sulcus, three in the fold, and six on the flanks. Fine pustulose microornament well defined in the interspaces between costae. Growth lines developed. 
Dorsal interior with a thin, blade-like cardinal process extends over the full length of the wide and highly raised notothyrial platform. Brachiophores low, with bases subtriangular in cross-section. Dental sockets shallow, like narrow slits. Median ridge low, extending to about mid-valve. Adductor muscle scars weakly impressed. Interior surface of valve faintly crenulated.

Discussion. Originally the name Platystrophia dentata.(Pander, 1830, p. 96, pl. XI, fig. 4) was assigned to a specimen with two costae in the sulcus and three costae in the fold. Precise stratigraphic position of the very schematically illustrated specimen is unknown. Pander's localities are situated in the environs of St. Petersburg (Izhora, Popovka, Pulkovka rivers and other outcrops) where the rocks range stratigraphically from the Volkhov Stage to the Lasnamägi Stage. However, in subsequent publications the name Platystrophia dentata (Pander) was attributed to the shells having two costae in the sulcus and three costae in the fold, but being distributed from Llandeilo to Wenlock. No doubt they represent different species and therefore only one shell can be identified as Platystrophia dentata.

Exteriorly the specimens described herein closely resemble the shell illustrated by Verneuil (1845, p. 138, pl. III, figs. 5a-e), only slightly differing in having a somewhat narrower sulcus and greater height of interareas. However, these specimens differ from the typical specimens illustrated by Pander (1830) in having a rounded subrectangular shell outline, wider and deeper sulcus, and a high fold.

Platystrophia ex. gr. $P$. dentata has the same number of costae in the sulcus and fold as Platystrophia sp. Neuman (1964, p. 17, pl. 2, figs. 12-18) from the late Arenig-early Llanvirn, NE Maine, USA, and Platystrophia dongbeiensis Liu, Zhy \& Xue (1985, p. 20, pl. 2, figs. 12-25) from the late Arenig of NE China, but differs in having more costae on the flanks and longer and wider interareas.

Platystrophia ex. gr. P. dentata differs from Platystrophia putilovensis sp. nov. in suboval shell outline, short hinge line, and in the interior of the dorsal valve it has a lower median ridge, longer cardinal process and deeper dental sockets.

Occurrence. Volkhov Stage, Volkhov Formation (Microzarkodina flabellum parva Zone) - Putilovo quarry, Simankovo village; St. Petersburg region, northwest Russia.

\author{
Platystrophia? sp. 1 \\ Plate II, figures 10, 11
}

Material. 1 ventral valve.

Description. Ventral valve moderately and evenly convex, subquadrate in outline, with the maximum width at about mid-valve; length $10.5 \mathrm{~mm}$, width 
$12+\mathrm{mm}$. Cardinal extremities nearly right-angled. Interarea high, apsacline, curved. Delthyrium open, triangular, moderately wide. Sulcus originates in the umbonal area; it is narrow and shallow in the posterior third of the valve but strongly deepened and widened towards the anterior margin. Pustulose microornament not observed. Radial ornament contains 2 angular costae in the sulcus and 9 costae on the flanks. Growth lines present. Ventral interior with prominent teeth, subparallel dental plates, muscle field situated on pseudospondylium. The crural fossettes are very shallow on the inner face of the teeth. Muscle scars absent. Interior surface of the valve faintly crenulated in the anterior one-third of the valve.

Discussion. Externally Platystrophia? sp. 1 is similar to the ventral valve of Platystrophia sp. a Rubel (1961, p. 154, pl. I, figs. 4, 5) from the lower Volkhov Stage of the St. Petersburg region, but differs internally in the absence of a low median ridge between diductor scars posteriorly as well as in having faint crenulations in the anterior one-third of the valve. The unproved pustulose microornament and lack of the dorsal valve makes the generic attribution of both forms slightly tentative.

Occurrence. Volkhov Stage, Volkhov Formation (upper Baltoniodus triangularis-B. navis Zone) - Putilovo quarry; St. Petersburg region, northwest Russia.

\section{Platystrophia? sp. 2}

Plate II, figure 12

Material. 1 ventral valve.

Description. Ventral valve moderately convex, transverse, subrectangular in outline, with the maximum width at mid-valve; length $10 \mathrm{~mm}$, width $14+\mathrm{mm}$. Interarea about $0.6 \mathrm{~mm}$ high, nearly planar, apsacline, with open triangular, moderately wide delthyrium. Beak slightly erected. Sulcus deep and broad, with steep lateral sides. Margins of sulcus diverge at about $44^{\circ}$. Sulcus ends with the tongue $5 \mathrm{~mm}$ in length. Radial ornament costate, with 3 simple costae in the sulcus and 7 ones on the flanks. Ventral interior with short triangular teeth, subparallel dental plates, and a muscle field on the pseudospondylium. The crural fossettes developed on the inner side of teeth. Growth lines and granules absent.

Discussion. Platystrophia? sp. 2 has three costae in the sulcus like Platystrophia lynx Eichwald, as described by Alikhova (1951) from the Jõhvi Stage of the St. Petersburg region, but differs in having subrectangular transverse shell outline, a wider and deeper sulcus, and less costae on the flanks.

The described specimen differs from Platystrophia? sp. Neuman \& Bates (1978, p. 589, pl. 68, figs. 17-24) from the early Llanvirn of northwest Wales in having smaller rounded costae and a deeper sulcus with the well-developed tongue. 
Occurrence. Kunda Stage, Obukhovo Formation (upper Eoplacognathus variabilis Zone) - Kipen village; St. Petersburg region, northwest Russia.

\author{
Platystrophia? sp. 3 \\ Plate II, figures 13,14
}

Material. 1 complete shell.

Description. Length $9.6 \mathrm{~mm}$, width $9.5+\mathrm{mm}$. The poorly preserved shell has a $0.3 \mathrm{~mm}$ high, nearly planar, apsacline and short ventral interarea. Ventral sulcus and dorsal median fold originate at $1.5 \mathrm{~mm}$ from the umbo. Margins of sulcus diverge at about $42^{\circ}$. Radial ornament costate; 4 rounded costae are developed in the sulcus, 5 costae in the fold, and up to 8 costae on flanks. Growth lines and pustulose microornament not detected.

Discussion. This form is somewhat similar to Spirifer lynx Verneuil (1845, p. 136, pl. III, fig. 4b) from the Ordovician (exact locality and horizon uncertain) of the St. Petersburg region, but differs in having more costae in the sulcus and fold.

Occurrence. Kunda Stage, Obukhovo Formation (upper Eoplacognathus variabilis Zone) - Kirchoff Mountain; St. Petersburg region, northwest Russia.

\title{
ACKNOWLEDGEMENTS
}

I am grateful to J. L. Benedetto (Universidad Nacional de Cordoba, Argentina), A. V. Dronov (St. Petersburg State University), L. Hints (Institute of Geology, Tallinn Technical University), Rong Jia-yu (Nanjing Institute of Geology and Paleontology), M. Rubel (Institute of Geology, University of Tartu), A. V. Zhuravlev (VSEGEI), and S. S. Terentiev (Mining Institute, St. Petersburg) for their assistance at different stages of the preparation of the paper. My special thanks are to R. B. Neuman (Smithsonian Institution, Washington) for much useful advice, T. L. Modzalevskaya and L. E. Popov (VSEGEI) for critical comments on the manuscript. Photos were made by B. S. Pogrebov (St. Petersburg State University).

This study is a contribution to the IGCP Project No. 410 "Ordovician Biodiversification Event". Different stages of the work were funded by the Paleontological Society and administered by the U.S. Civilian Research \& Development Foundation for the Independent States of the Former Soviet Union (CRDF) and by grant No. s97-173 of the International Soros Science Education Program. 


\section{REFERENCES}

Alikhova, T. N. 1951. Brakhiopody srednej $i$ verkhnej chasti nizhnego silura Leningradskoj oblasti $i$ ikh stratigraficheskoe znachenie. Gosudarstvennoe Izdatel'stvo Geologicheskoj Literatury, Moskva (in Russian).

Benedetto, J. L. 1998. Early Palaeozoic brachiopods and associated shelly faunas from western Gondwana: their bearing on the geodynamic history of the pre-Andean margin. In The Proto-Andean Margin of Gondwana (Pankhurst, R. J. \& Rapela, C. W., eds). Geol. Soc. London Spec. Publ., 142, 57-83.

Benedetto, J. L. \& Herrera, Z. A. 1987. The genus Platystrophia King (Brachiopoda) in the San Juan Formation of the Argentinian Precordillera. Ameghiniana, 24, 1-2, 51-59.

Bondarev, V. I. 1968. Stratigraphy and characteristic brachiopods of the Ordovician deposits of southern Novaya Zemlya, Vaigach Island and northern Paj-Khoj. Trudy NIIGA, 157, 3-144 (in Russian).

Cummings, E. R. 1903. The morphogenesis of Platystrophia. A study of the evolution of a Paleozoic brachiopod. Am. J. Sci., XV.

Dronov, A. V. \& Fedorov, P. V. 1995. Ordovician carbonates of the St. Petersburg region: stratigraphy of the Zheltyaki and Frizi beds. Vestnik Sankt-Peterburgskogo universiteta 7 , geologiya, geografiya, 2, 14, 9-16 (in Russian).

Dronov, A. V., Savitsky, Yu. V., Fedorov, P. V. \& Tsyganova, E. A. 1996. Detailed lithostratigraphy of the Ordovician lower Volkhovian limestone along the eastern part of the BalticLadoga Glint, northwestern Russia. GFF, 118, 19-24.

Dronov, A. V., Koren, T. N., Popov, L. E. \& Tolmacheva, T. Yu. 1998. Event Stratigraphy Approach Applied to Regional Correlation. VSEGEI, St. Petersburg (in Russian).

Eichwald, E. 1841. Ueber das silurischen Schichtensystem in Estland. J. für Natur- und Heilkunde, herausgegeben von Kais. medico chirurgischen. Akad., St.-Petersburg, 2.

Eichwald, E. 1861. Paleontologiya Rossii. Drevnij period. St. Petersburg (in Russian).

Fortey, R. A., Harper, D. A. T., Ingham, A. W., Owen, A. W. \& Rushton, A. W. A. 1995. A revision of the Ordovician series and stages from the historical type area. Geol. Mag., 132, $1,15-30$.

Hiller, N. 1980. Ashgill Brachiopoda from the Glyn Ceiriog District, north Wales. Bull. Brit. Mus. Nat. Hist. Geol., 34, 3, 109-216.

Liu, Di-Yong, Zhy, Ci-Ying \& Xue, Chun-Ting. 1985. Ordovician brachiopods from Northwestern Xiao Hinggan, Northeast China. Bull. Shenyang Inst. Geol. Min. Res., 11, 1-46.

McEwan, E. D. 1919. A study of the brachiopod genus Platystrophia. Proc. US Nat. Mus., 56.

Neuman, R. B. 1964. Fossils in Ordovician tuffs, northeastern Maine. US Geol. Surv. Bull., 1181-E, $1-38$.

Neuman, R. B. 1976. Early Ordovician (Late Arenig) brachiopods from Virgin Arm, New World Island, Newfoundland. Geol. Surv. Can. Bull., 261, 11-61.

Neuman, R. B. 1984. Geology and paleobiology of islands in the Ordovician Iapetus Ocean: review and implications. Geol. Soc. Amer. Bull., 95, 1188-1201.

Neuman, R. B. \& Bates, D. E. B. 1978. Reassessment of Arenig and Llanvirn age (Early Ordovician) brachiopods from Anglesey, N-W. Wales. Palaeontology, 21, 3, 571-613.

Pander, C. H. 1830. Beiträge zur Geognosie des russischen Reiches. St.-Petersburg.

Rubel, M. P. 1961. Lower Ordovician brachiopods of the superfamilies Orthacea, Dalmanellacea and Syntrophiacea of Eastern Baltic. ENSV TA Geol. Inst. Uurimused, 6, 141-226 (in Russian).

Verneuil, E. P. 1845. Paleontologie. In Geologie de la Russie d'Europe et des Montagnes de l'Oural (Murchison, R. I., Verneuil, E. P. \& Keyserling, A., eds.), Vol. 2, pt. 3. Paris.

von Buch, L. 1837. Über Delthyris oder Spirifer und Orthis. Berlin.

von Buch, L. 1840. D'une Classification et d'une Description des Delthyris ou Spirifer et Orthis. Mem. Soc. Geol. France, Ser. 1, Vol. IV, pt. 1. 


\section{ARENIGI JA ALAM-LLANVIRNI PLATYSTROPHIA (ORTHIDA, BRACHIOPODA) LOODE-VENEMAAL}

\section{Mihhail ZUIKOV}

On kirjeldatud brahhiopoodide perekonna Platystrophia vanimaid esindajaid Loode-Venemaa ordoviitsiumi läbilõigetes. Üks kuuest vaadeldavast taksonist esindab uut ja üks varem tuntud liiki ning nelja on kirjeldatud kui morfoloogiliselt erinevaid vorme, mis võivad kuuluda eri liikidesse. Vanimaks perekond Platystrophia esindajaks Baltoskandias on Platystrophia sp. a Rubel, 1961, mis esineb Leningradi oblastis Volhovi lademe alumises osas (konodonditsooni Baltoniodus triangularis-B. navis ülemises osas). Sellel liigil puudub aga Platystrophia perekonnale iseloomulik kaane välisskulptuuri element - granulatsioon. Samalt stratigraafiliselt tasandilt leitud eksemplar, millel on samuti ebatüüpiline kaane skulptuur, on arvatud sellesse perekonda tinglikult.

Venemaal, Walesis, Põhja-Ameerikas, Lõuna-Ameerikas ja Hiinas esinevate Ülem-Arenigi ja Alam-Llanvirni ealiste Platystrophia liikide leviku analüüs näitab, et vanim Platystrophia sp. võib pärineda Argentiinast (tsooni Baltoniodus triangularis-B. navis alumisest osast). Nii nagu Baltoskandias, on ka Argentiinas Platystrophia hulka kuuluvatel vanimatel eksemplaridel (kirjeldatud kui Platystrophia sp.) perekonnale ebatüüpiline skulptuur. Perekonna diagnostikas kasutatavad kaane välisskulptuuri tunnused vajavad lisauurimist.

\section{PLATYSTROPHIA (ORTHIDA, BRACHIOPODA) ИЗ АРЕНИГА И НИЗОВ ЛЛАНВИРНА СЕВЕРО-ЗАПАДА РОССИИ}

\section{Михаил ЗУЙКОВ}

Из аренига и низов лланвирна российской части Балтийско-Ладожского глинта описаны шесть представителей рода Platystrophia - два вида (один из которых новый) и четыре формы в открытой номенклатуре. Древнейшим представителем рода в ордовике Балтоскандии является Platystrophia sp. a, описанная Рубелем (1961) из низов волховского горизонта (верхняя часть конодонтовой зоны Baltoniodus triangularis-B. navis) Ленинградской области. Последняя, однако, не имеет грануляции на внешней поверхности раковины, и поэтому сходный экземпляр, обнаруженный в одновозрастных отложениях, в настоящей работе отнесен к роду условно.

Приведенные данные о распространении платистрофий в верхнем арениге-нижнем лланвирне России, Уэльса, Северной Америки, Южной Америки и Китая показывают, что самым древним представителем рода является Platystrophia sp. из аренига Аргентины (нижняя часть зоны Baltoniodus triangularis-B. navis). Несмотря на хорошую сохранность внешней поверхности раковины, данный вид не имеет грануляции, что делает его родовое определение дискуссионным. 